\title{
FAKTOR-FAKTOR YANG MEMPENGARUHI NILAI PERUSAHAAN NON KEUANGAN YANG TERDAFTAR DI BURSA EFEK INDONESIA
}

\author{
ANWAR HARSONO \\ STIE Trisakti \\ anwar@dosen.stietrisakti.ac.id
}

\begin{abstract}
The objective of the research is to obtain empirical evidence on the effect of independent variables of firm size, cash, capital expenditure, dividend policy, debt policy, return on asset, managerial ownership, and institutional ownership to firm value. The population used in this study are non-financial companies listed on the Indonesia Stock Exchange from 2013-2016. Intake of data in this research using purposive sampling method. There are 54 non-financial companies that fit the criteria and were selected as the final sample. This study uses multiple regression analysis to test the hypothesis. The value of firms in this study was measured using Tobins'Q.The empirical results of this study indicate that the variables independent debt policy and return on assets have an influence on firm value, while the variables of firm size, cash, capital expenditure, dividend policy, managerial ownership, and institutional ownership have no effect on firm value.
\end{abstract}

Keywords: Tobins'Q, firm value, cash, capital expenditure, debt policy, institusional ownership

Abstrak: Tujuan penelitian adalah untuk memperoleh bukti empiris mengenai pengaruh dari variabel-variabel independen ukuran perusahaan, kas, belanja modal, kebijakan dividen, kebijakan utang, return on asset, kepemilikan manajerial, dan kepemilikan institusional terhadap nilai perusahaan. Populasi yang digunakan dalam penelitian ini adalah perusahaan non keuangan yang terdaftar di Bursa Efek Indonesia dari tahun 2013-2016. Pengambilan data dalam penelitian ini menggunakan metode purposive sampling. Terdapat 54 perusahaan non keuangan yang sesuai dengan kriteria dan terpilih sebagai sampel akhir. Penelitian ini menggunakan analisa regresi berganda unutk menguji hipotesis. Nilai perusahaan dalam penelitian ini diukur menggunakan Tobins'Q. Hasil empiris dari penelitian ini menunjukkan variabel inpenden kebijakan utang dan return on asset memiliki pengaruh terhadap nilai perusahaan, sedangkan variabel inpenden ukuran perusahaan, kas, belanja modal, kebijakan dividen, kepemilikan manajerial, dan kepemilikan institusional tidak memiliki pengaruh terhadap nilai perusahaan.

Kata Kunci: Tobins'Q, nilai perusahaan, kas, belanja modal, kebijakan utang, kepemilikan institusional

\section{PENDAHULUAN}

Perekonomian di setiap negara berkembang sangat pesat. Hal ini dikarenakan efek dari globaliasi yang terjadi dan mempengaruhi perekonomian di setiap negara. Globalisasi ekonomi dapat didefinisikan sebagai suatu kehidupan ekonomi secara global dan terbuka, tanpa mengenal batasan teritorial atau kewilayahan antara negara satu sama lain. Globalisasi ekonomi erat kaitannya dengan perdagangan bebas. Free trade atau perdagangan bebas berusaha menciptakan kawasan perdagangan yang makin luas dan menghilangkan hambatan-hambatan tidak lancarnya perdagangan internasional. Kegiatan 
perdagangan internasional adalah tindakan yang akan dilakukan oleh setiap perusahaan untuk memaksimalkan laba perusahaan yang merupakan salah satu tujuan dari sebuah perusahaan.

Secara umum, tujuan utama perusahaan dibagi menjadi 2, yaitu tujuan jangka pendek dan tujuan jangka panjang. Tujuan jangka pendek perusahaan adalah memperoleh laba secara maksimal dengan memaksimalkan sumber daya yang ada. Sedangkan tujuan jangka panjang perusahaan adalah meningkatkan nilai perusahaan dimana nilai perusahaan akan tergambar dari harga saham perusahaan yang bersangkutan. Tujuan perusahaan lainnya adalah memaksimalkan kemakmuran pemilik perusahaan atau pemegang saham. Tujuan tersebut dapat tercapai dengan memaksimalkan nilai perusahaan (Mangantar dan Ali 2015). Nilai perusahaan tercermin melalui nilai pasar (market value) saham perusahaan. Jika nilai saham perusahaan tinggi maka, nilai perusahaan juga akan tinggi, dan itu berarti tingkat kemakmuran para pemegang saham juga tinggi.

Tidak semua saham perusahaan bisa dibeli dan dimiliki oleh calon pemegang saham dan calon investor. Hanya perusahaan go public yang bisa menjual sahamnya kepada masyarakat secara bebas dan saham tersebut bisa dibeli dan dimiliki oleh calon pemegang saham dan calon investor.Nilai perusahaan bagi perusahaan go public sangatlah penting karena nilai perusahaan akan mencerminkan berhasil atau tidaknya kinerja sebuah perusahaan dalam menjalankan kegiatan operasionalnya. Oleh sebab itu, sebuah perusahaan go public haruslah memiliki nilai perusahaan yang baik dan juga harus selalu meningkatkan nilai perusahaan dengan cara memaksimalkan faktor-faktor yang mempengaruhi peningkatan nilai perusahaan di perusahaan tersebut agar calon pemegang saham percaya dan yakin bawah perusahaan tersebut layak untuk diinvestasikan.

\section{Agency Theory}

Jensen dan Meckling (1976) menjelaskan bahwa agency theory merupakan teori yang menjelaskan hubungan-hubungan yang berupa kontrak antara pihak equityholders atau investor yang kemudian disebut principal dengan pihak manajemen yang kemudian disebut sebagai agen. Pihak agen merupakan pihak yang dikontrak oleh pihak principal dan bertanggung jawab kepada pihak principal demi kepentingannya. Pihak agen diberikan wewenang dalam pengambilan keputusan perusahaan. Karena pihak agen telah mendapatkan mandat tersebut, maka mereka harus mempertanggungjawabkan semua pekerjaannya kepada pihak principal yang telah mendelegasikan tanggung jawab kepada mereka. Jika kedua belah pihak tersebut memiliki tujuan yang sama yaitu memaksimalkan nilai perusahaan, maka pihak agen akan menggunakan wewenangnya demi kepentingan pihak principal.

Menurut Godfrey et al. (2010), masingmasing pihak berusaha untuk memaksimalkan keuntungan bagi dirinya sendiri. Pihal principal (pemilik) pastinya mengharapkan pengembalian yang sebesar-besarnya dan secepatnya atas investasi yang dilakukannya. Sedangkan pihak agen (manajemen) seolah-olah ingin memaksimalkan prinsip kesejahteraan. Nilai perusahaan dapat meningkat jika kepentingan antara pihak principal dan agen dapat disatukan, tentunya akan ada biaya kegaenan yang timbul untuk menyatukan kepentingan tersebut, jika biaya keagenan yang timbul dapat diminimalisir maka nilai perusahaan dapat ditingkatkan.

\section{Signaling Theory}

Modigliani dan Miller bearsumsi bahwa investor dan manajer memiliki informasi yang sama tentang prospek perusahaan yang disebut dengan symmetric information. Walaupun, pada faktanya, manajer lebih sering memiliki informasi yang lebih baik dalam arti informasi yang lebih banyak dan lebih lengkap dibandingkan dengan informasi yang dimiliki investor. Kesenjangan 
informasi yang dimiliki investor dan manajer ini disebut dengan asymmetric information, yang kemudian memiliki efek yang penting terhadap struktur modal optimal perusahaan (Brigham dan Houston 2010).

Signaling theory juga menjelaskan mengapa perusahaan mempunyai dorongan untuk memberikan infomasi laporan keuangan pada pihak eksternal. Dorongan perusahaan untuk memberikan informasi tersebut adalah karena terdapat asimetri informasi antara perusahaan dan pihak investor karena perusahaan mengetahui lebih banyak mengenai perusahaan dan prospek yang akan datang dibanding pihak luar (investor, kreditor). Pada motivasi signaling manajemen melakukan kebijakan akrual yang mengarah pada presistensi laba. Motivasi signaling mendorong manajemen menyajikan laporan laba yang dapat mencerminkan laba sesungguhnya (Susilowati dan Turyanto 2011).

\section{Ukuran Perusahaan dan Nilai Perusahaan}

Rizqia et al. (2013) berpendapat bahwa ukuran perusahaan menggambarkan tingkat perusahaan berkembang dalam bisnisnya. Ukuran perusahaan akan berpengaruh terhadap kemudahan perusahaan dalam memperoleh utang. Di mana perusahaan besar memiliki aktiva yang besar yang dapat dijaminkan dalam memperoleh utang sebagai sumber pendanaan. Karena itu ukuran perusahaan akan berpengaruh terhadap akses perusahaan untuk memperoleh sumber pendanaan. Berdasarkan pengembangan diatas, maka hipotesis yang diajukan adalah:

$\mathrm{H}_{1}$ Ukuran perusahaan berpengaruh terhadap nilai perusahaan.

\section{Kas dan Nilai Perusahaan}

Kas adalah asset yang paling likuid, termasuk mata uang yang tersedia dan dana deposito (Subramanyam 2014). Syafrizaliadhi dan Arfianto (2014) menyatakan bahwa kas merupakan aset perusahaan paling likuid yang berfungsi sebagai darah perusahaan dalam menggerakkan operasi rutin. Kegagalan perusahaan dalam menghadapi kesulitan keuangan telah memfokuskan perhatian pada pentingnya kepemilikan uang tunai. Kas juga merupakan sebuah aset yang tidak dapat menghasilkan sebuah keuntungan secara langsung dalam operasional perusahaan. Menurut Azmat (2014), kas merupakan komponen terpenting dalam perusahaan. Karena berlaku sebagai alat tukar dalam perekonomian, kas terlihat secara langsung atau tidak langsung dalam hampir semua transaksi usaha. Berdasarkan pengembangan diatas, maka hipotesis yang diajukan adalah:

$\mathrm{H}_{2}$ Kas berpengaruh terhadap nilai perusahaan.

\section{Belanja Modal dan Ukuran Perusahaan}

Belanja modal (capital expenditure) selisih antara asset total saat ini dengan asset total pada periode sebelumnya (Adi dan Muid 2013). Bashir et al. (2014) berpendapat bahwa belanja modal yang semakin besar menunjukkan investasi yang dilakukan juga besar. Investasi yang dilakukan perusahaan dapat menjadi gambaran dari kinerja perusahaan dimasa lalu sebagai ekspansi dan merancang kelangsungan kinerjanya di masa yang akan datang. Perusahaan yang memiliki peluang investasi yang lebih besar memiliki pertumbuhan yang lebih besar dapat dinilai melalui belanja modal perusahaan. Berdasarkan pengembangan diatas, maka hipotesis yang diajukan adalah:

$\mathrm{H}_{3}$ Belanja modal berpengaruh terhadap nilai perusahaan.

\section{Kebijakan Dividen dan Nilai Perusahaan}

Kebijakan dividen (dividend policy) merupakan penentuan penempatan laba antara membayar kepada pemegang saham atau menginvestasikan kembali dalam perusahaan. Laba ditahan (retained earnings) merupakan salah satu dari sumber dana yang paling penting untuk membiayai pertumbuhan perusahaan, 
tetapi dividen merupakan arus kas yang disisihkan untuk pemegang saham (Weston dan Copeland 1991). Gordon and Litnert theory menyatakan bahwa dividen memiliki resiko yang lebih kecil daripada capital gains karena dividend payout ratio menawarkan dividend yield yang tinggi yang mampu meningkatkan harga saham. Signaling theory berasumsi bahwa informasi dividen dapat berarti kabar baik bagi investor karena perusahaan memiliki arus kas bebas dari operasi untuk dibagikan (Gamayuni 2015). Berdasarkan pengembangan diatas, maka hipotesis yang diajukan adalah:

$\mathrm{H}_{4}$ Kebijakan dividen berpengaruh terhadap nilai perusahaan.

\section{Kebijakan Utang dan Nilai Perusahaan}

Struktur modal menurut Meidiawati dan Mildawati (2016) adalah perbandingan atau imbangan pendanaan jangka panjang perusahaan yang ditunjukkan oleh perbandingan utang jangka panjang terhadap modal sendiri. Pemenuhan kebutuhan dana perusahaan dari sumber modal sendiri berasal dari modal saham, laba ditahan, dan cadangan. Jika dalam pendanaan perusahaan yang berasal dari modal sendiri masih mengalami kekurangan (defisit) maka perlu dipertimbangkan pendanaan perusahaan yang berasal dari luar, yaitu dari utang (debt financing). Berdasarkan pengembangan diatas, maka hipotesis yang diajukan adalah:

$\mathrm{H}_{5}$ Kebijakan utang berpengaruh terhadap nilai perusahaan.

\section{Return on Asset dan Nilai Perusahaan}

Profitabilitas (profitability) menurut Rizqia et al. (2013) merupakan sebuah pengukuran efektifitas manajemen berdasarkan tingkat pengembalian dari penjualan dan investasi. Dalam analisis rasio, kemampuan menghasilkan laba dapat dikaitkan dengan penjualan aset atau modal. Berdasarkan pengembangan diatas, maka hipotesis yang diajukan adalah:
$\mathrm{H}_{6}$ Return on asset berpengaruh terhadap nilai perusahaan.

\section{Kepemilikan Manajerial dan Nilai Perusahaan} Menurut Rizqia et al. (2013), kepemilikan manajerial diartikan sebagai hasil dari realisasi dan upaya perusahaan untuk mengurangi masalah keagenan. Hal ini akan mengurangi kemungkinan manajemen perusahaan melakukan tindakan negatif dan merugikan kepentingan pemegang saham, karena mereka sendiri juga merupakan bagian dari pemegang saham yang ikut merasakan jika terjadi dampak negatif yang dialami oleh perusahan. Berdasarkan pengembangan diatas, maka hipotesis yang diajukan adalah:

$\mathrm{H}_{7}$ Kepemilikan manajerial berpengaruh terhadap nilai perusahaan.

\section{Kepemilikan Institusional dan Nilai Perusahaan}

Kepemilikan institusional adalah kepemilikan saham perusahaan yang dimiliki oleh institusi atau lembaga seperti perusahaan asuransi, bank, perusahaan investasi dan kepemilikan institusi lain (Tarjo 2008). Menurut Kaluti dan Purwanto (2014), adanya kepemilikan institusional mampu mengatasi konflik keagenan karena kinerja manajer dapat dimonitoring dengan efektif. Kepemilikan institusional memberikan pengawasan terhadap kinerja manajemen khususnya dalam hal penggunaan dana perusahaan. Semakin besar kepemilikan institusional maka penggunaan dana perusahaan akan semakin efisien dan mencegah terjadinya pemborosan yang dilakukan oleh manajer. Hal itu berarti bahwa nilai perusahaan juga meningkat. Berdasarkan pengembangan diatas, maka hipotesis yang diajukan adalah:

$\mathrm{H}_{8}$ Kepemilikan institusional berpengaruh terhadap nilai perusahaan. 


\section{METODA PENELITIAN}

Populasi yang digunakan dalam penelitian ini adalah perusahaan non keuangan yang terdaftar di Bursa Efek Indonesia pada tahun 2013-2016. Teknik pemilihan sampel yang digunakan adalah metode purposive sampling. Hasil pemilihan sampel dapat dilihat pada tabel 1 berikut ini:

Tabel 1 Prosedur Pemilihan Sampel

\begin{tabular}{|c|c|c|}
\hline Kriteria Sampel & $\begin{array}{c}\text { Jumlah } \\
\text { Perusahaan }\end{array}$ & $\begin{array}{c}\text { Jumlah } \\
\text { Data }\end{array}$ \\
\hline $\begin{array}{l}\text { Perusahaan non keuangan yang secara konsisten terdaftar } \\
\text { di Bursa Efek Indonesia pada tahun } 2013 \text { sampai dengan } \\
\text { tahun } 2016 \text {. }\end{array}$ & 407 & 1221 \\
\hline $\begin{array}{l}\text { Perusahaan non keuangan yang tidak secara konsisten } \\
\text { melakukan tutup buku yang berakhir pada } 31 \text { Desember } \\
\text { pada tahun } 2013 \text { sampai dengan tahun } 2016 \text {. }\end{array}$ & (6) & $(18)$ \\
\hline $\begin{array}{l}\text { Perusahaan non keuangan yang tidak secara konsisten } \\
\text { menggunakan mata uang rupiah dalam penyajian laporan } \\
\text { keuangannya pada tahun } 2013 \text { sampai dengan tahun } 2016 \text {. }\end{array}$ & $(72)$ & $(216)$ \\
\hline $\begin{array}{l}\text { Perusahaan non keuangan yang tidak secara konsisten } \\
\text { memiliki pemegang saham manajerial pada tahun } 2014 \\
\text { sampai dengan tahun } 2016 \text {. }\end{array}$ & $(189)$ & $(567)$ \\
\hline $\begin{array}{l}\text { Perusahaan non keuangan yang tidak secara konsisten } \\
\text { memiliki pemegang saham institusional pada tahun } 2014 \\
\text { sampai dengan tahun } 2016 \text {. }\end{array}$ & (5) & $(15)$ \\
\hline $\begin{array}{l}\text { Perusahaan non keuangan yang secara konsisten } \\
\text { membagikan dividen tunai kepada para pemegang saham } \\
\text { pada tahun } 2014 \text { sampai dengan tahun } 2016 \text {. }\end{array}$ & (81) & $(243)$ \\
\hline Total data yang digunakan dalam periode penelitian & 54 & 162 \\
\hline
\end{tabular}

Nilai perusahaan (Tobin'S Q) merupakan persepsi investor terhadap perusahaan yang sering dihubungkan dengan harga saham (Moniaga 2013). Menurut Malan et al. (2013), pengukuran variabel nilai perusahaan diukur dengan skala rasio metode Tobin'S Q sebagai berikut:

Tobin'S Q = Market Value of Equity + Total Debt

Ukuran perusahaan dinyatakan sebagai besar kecilnya suatu perusahaan yang dilihat dari nilai buku aktiva yang dimiliki oleh perusahaan tersebut (Debby et al. 2014). Menurut Malan et al. (2013), ukuran perusahaan diukur dengan skala rasio sebagai berikut:
SIZE = Ln (Total Asset)

Kas merupakan salah satu bagian dari aktiva yang memiliki sifat paling lancar (paling likuid) dan paling mudah berpindah tangan dalam suatu transaksi dalam suatu perusahaan. Menurut Malan et al. (2013), kas diukur dengan skala rasio sebagai berikut:

$\mathrm{CASH}=\mathrm{Ln}$ (Cash)

Belanja modal adalah biaya-biaya yang dikeluarkan dalam rangka memperoleh aktiva tetap, meningkatkan efisiensi operasional dan kapasitas produktif aktiva tetap, serta memperpanjang masa manfaat aktiva tetap. Menurut Malan et al. (2013), belanja modal diukur dengan skala rasio sebagai berikut: 


$$
\text { CAPEX }=\frac{\text { Total Fixed Asset }}{\text { Total Asset }}
$$

Kebijakan dividen merupakan penentuan penempatan laba antara membayar kepada pemegang saham atau menginvestasikan kembali dalam perusahaan (Weston dan Copeland 1991). Menurut Kieso et al. (2014), kebijakan dividen diukur dengan skala rasio sebagai berikut:

$$
\begin{aligned}
& \text { DIVR }=\frac{\text { Cash Dividends }}{\text { Net Income }- \text { Preference Dividends }} \\
& \text { Kebijakan utang (DEBTR) diukur }
\end{aligned}
$$
dengan perhitungan leverage. Financial leverage mengukur seberapa banyak proporsi ekuitas dan utang yang digunakan perusahaan untuk mendanai asetnya (Rehman 2013). Menurut Malan et al. (2013), kebijakan utang diukur dengan skala rasio sebagai berikut:

$$
\begin{aligned}
& \text { DEBTR }=\frac{\text { Total Debt }}{\text { Total Asset }} \\
& \text { Return on asset merupakan }
\end{aligned}
$$
kemampuan perusahaan menggunakan sumber daya aset untuk menghasilkan keuntungan (Rizqia et al. 2013). Menurut Rizqia et al. (2013), return on asset diukur dengan skala rasio sebagai berikut:

$$
\begin{aligned}
& \mathrm{ROA}=\frac{\text { Net Income }}{\text { Total Assets }} \\
& \text { Kepemilikan manajerial merupakan }
\end{aligned}
$$
proporsi saham biasa yang dimiliki oleh pihak manajemen perusahaan (direksi dan komisaris) (Prastuti dan Budiasih 2015). Menurut Rizqia et al. (2013), kepemilikan manajerial diukur dengan skala rasio sebagai berikut:

$$
\mathrm{KM}=\frac{\text { Jumlah Saham yang Dimiliki Komisaris dan Direksi }}{\text { Jumlah Saham Beredar }}
$$
persentase saham yang dimiliki oleh investor institusi seperti perusahaan asuransi, perusahaan investasi, dan bank (Moradi et al. 2012). Menurut Putri dan Suprasto (2016), kepemilikan institusional diukur dengan skala rasio sebagai berikut:

$$
\mathrm{KI}=\frac{\text { Jumlah Saham yang Dimiliki Institusional }}{\text { Jumlah Saham Beredar }} \times 100 \%
$$

\section{HASIL PENELITIAN}

Hasil statistik deskriptif dan hasil pengujian hipotesis dapat dilihat pada tabel 2 dan tabel 3 berikut ini:

Tabel 2 Statistik Deskriptif

\begin{tabular}{llrrrr}
\hline Variabel & $\mathrm{N}$ & Minimum & Maksimum & Rata-rata & Std. Deviasi \\
\hline TOBINSQ & 162 &, 49231002 & 11,08718341 & 1,737414176 & 1,456312533 \\
SIZE & 162 & 24,89924137 & 33,19881203 & 29,23759765 & 1,706143258 \\
CASH & 162 & 22,70850915 & 31,02442151 & 26,82446491 & 1,892422369 \\
CAPEX & 162 &, 01653570 &, 87724867 &, 2798053234 &, 1904941721 \\
DIVR & 162 & $-4,45311959$ & 1,32733890 &, 2936358097 &, 4217987908 \\
DEBTR & 162 &, 07424251 &, 78994472 &, 4268376742 &, 1867279694 \\
ROA & 162 &,- 01714999 &, 33324523 &, 0740477977 &, 0586119179 \\
KM & 162 &, 00000022 &, 40835914 &, 0389093432 &, 0741490593 \\
KI & 162 &, 22478402 &, 96091151 &, 6260415958 &, 1526026948 \\
\hline
\end{tabular}


Tabel 3 Hasil Pengujian Hipotesis

\begin{tabular}{lrrc}
\hline Variabel & \multicolumn{1}{c}{$\mathrm{B}$} & \multicolumn{1}{c}{$\mathrm{t}$} & \multicolumn{1}{c}{ Sig. } \\
\hline (Constant) & $-1,311$ &,- 795 &, 428 \\
SIZE &,- 018 &,- 156 &, 876 \\
CASH &, 057 &, 569 &, 571 \\
CAPEX &,- 733 & $-1,688$ &, 094 \\
DIVR &, 141 &, 781 &, 436 \\
DEBTR & 1,364 & 2,782 &, 006 \\
ROA & 19,783 & 14,119 &, 000 \\
KM & 1,315 &, 999 &, 319 \\
KI &, 198 &, 320 &, 749 \\
\hline
\end{tabular}

Berdasarkan hasil pengujian hipotesis, dapat disimpulkan bahwa ukuran perusahaan, kas, kebijakan dividen, kepemilikan manajerial, kepemilikan institusional tidak berpengaruh terhadap nilai perusahaan. Sementara kebijakan utang berpengaruh terhadap nilai perusahaan. Penggunaan utang dalam pendanaan perusahaan akan meningkatkan nilai perusahaan namun hanya sampai batas tertentu saja. Karena jika penggunaan utang melebihi batas tersebut akan menurunkan nilai perusahaan. Perusahaan harus dapat menentukan berapa besarnya utang yang akan digunakan oleh perusahaan agar dapat meningkatkan nilai perusahaan. $\mathrm{Hal}$ ini menunjukkan bahwa kebijakan penambahan utang merupakan sinyal positif bagi investor dan mempengaruhi nilai perusahaan. Return on asset berpengaruh terhadap nilai perusahaan. Return on asset merupakan salah satu rasio yang digunakan untuk mengukur profitabilitas perusahaan yaitu untuk mengukur kemampuan perusahaan dalam menghasilkan laba atau profit. Jika suatu perusahaan memiliki nilai return on asset yang tinggi, berarti kinerja dan efisiensi perusahaan tersebut adalah baik. Hal ini akan meningkatkan nilai perusahaan di mata para investor.

\section{PENUTUP}

Berdasarkan hasil penelitian dapat disimpulkan bahwa kebijakan utang dan return on asset berpengaruh terhadap nilai perusahaan. Sementara ukuran perusahaan, kas, belanja modal, kebijakan dividen, kepemilikan manajerial, dan kepemilikan institusional tidak berpengaruh terhadap nilai perusahaan. Penelitian ini memiliki keterbatasan, yaitu penelitian ini hanya menggunakan 8 variabel independen yang dimana hanya 2 variabel saja yang memberikan pengaruh. Rekomendasi bagi penelitian selanjutnya, yaitu: menambah variabel independen lain yang dapat berpengaruh terhadap nilai perusahaan seperti earning per share, pertumbuhan perusahaan, pertumbuhan penjualan, umur perusahaan, dan investment opportunity set.

\section{REFERENSI:}

Adi, Dimas Kusuma dan Dul Muid. 2013. Analisi Faktor-Faktor yang Mempengaruhi Capital Expenditure: Dengan Pendekatan pecking Order Theory (Studi Empris pada Perusahaan Manufaktur di BEI). Diponegoro Journal of Accounting, Vol. 2, No. 4, 1-15.

Azmat, Qurat-ul-ann. 2014. Firm Value and Optimal Cash Level: Evidence from Pakistan. International Journal of 
Emerging Markets, Vol. 9, №. 4, 488-504.

Bashir, Hamid, Khurram Suktan, dan Omar Khazaal Jghef. 2013. Impact of Derivatives Usage on Firm Value: Eviden from Non Financial Firms on Pakistan. Journal of Management Research, Vol. 5, No. 4 (Oktober), 118-127.

Brigham, Eugene F. dan Joel F. Houston. 2010. Essentials of Financial Management, $2^{\text {nd }}$ Edition. Singapore: Cengage Learning Asia Pte Ltd.

Debby, Julia Farah, Mukhtaruddin, Emylia Yuniarti, Dewa Saputra, dan Abukosim. 2014. Good Corporate Governance, Company's Characteristic and Firm Value: Empirical Study of Listed Banking on Indonesian Stock Exchange. Journal on Bussiness, Vol. 3. No. 4 (November), 81-88.

Jensen, Michel $\mathrm{C}$ and William H. Meckling. 1976. Theory of The Firm: Managerial Behavior, Agency Cost and Ownership Structure. Journal of Financial Economics, Vol. 3, No. 4, (Oktober), 305-360.

Kaluti, Stephani Novitasari Christianingsih, dan Agus Purwanto. 2014. Pengaruh Struktur Kepemilikan dan Kebijakan Keuangan terhadap Nilai Perusahaan (Studi Empiris pada Perusahaan Manufaktur yang terdaftar di Bursa Efek Indonesia Tahun 2010-2012). Diponegoro Journal of Accounting, Vol. 3, No. 2, $1-12$.

Kieso, Donald E., Jerry J. Weygandt, dan Terry D. Warfield. 2014. Intermediate Accounting, Second Edition. United States: John Wiley \& Sons, Inc.

Malan, Irfah Najihah Basir, Norhana Salamudin, dan Noryati Ahmad. 2013. Ownership and Control Divergence on Firm Value. Indian Journal of Commerce \& Management Studies, Vol. 1, No. 1, 78-85.

Mangantar, Maryam dan Muhammad Ali. 2015. An Analysis of the Influence of Ownership Structure, Investment, Liquidity, and Risk to Firm Value: Evidence from Indonesia. American Journal of Economics and Business Administration, Vol. 7, No. 4, 166-176.

Gamayuni, Rindu Rika. 2015. The Effect of Intangible Asset, Financial Performance and Financial Policies on the Firm Value. International Journal of Scientific \& Technology Research, Vol. 4, No.1, 202-212.

Godfrey, Jayne., Allan Hodgson, Ann Tarca, Jane Hamilton, and Scott Holmes. 2010. Accounting Theory, Seventh Edition. Australia: John Wiley \& Sons Australia Ltd.

Meidiawati, Karina dan Titik Mildawati. 2016. Pengaruh Size, Growth, Profitabilitas, Struktur Modal, Kebijakan Dividen terhadap Nilai Perusahaan. Jurnal IImu dan Riset Akuntansi, Vol. 5, No. 2 (Februari), 1-16.

Moniaga, Fernandes. 2013. Struktur Modal, Profitabilitas dan Struktur Biaya terhadap Nilai Perusahaan Industri Keramik, Porcelen dan Kaca Periode 2007-2011. Jurnal EMBA, Vol. 2, No. 3, 433-442.

Moradi, Nassim Shah, Mahmood Moein Aldin, Forough Heyrani, dan Mohsen Iranmahd. 2012. The Effect of Corporate Governance, Corporate Financing Decision and Ownership Structure of Firm Performance: A Panel Data Approach from Tehran Stock Exchange. International Journal of Economics and Finance, Vol 4, No. 6 (Juni), 86-93.

Prastuti, Ni ketut Karlina dan I Gusti Ayu Nyoman Budiasih, 2015. Pengaruh Good Corporate Governance pada Nilai Perusahaan dengan Moderasi Corporate Social Responsibility. E-Jurnal Akuntansi Universitas Udayana, Vol. 13 No. 1, 114-129.

Putri, Ida Ayu Sasmika dan Bambang Suprasto H. 2016. Pengaruh Tanggung Jawab Sosial Perusahaan dan Mekanisme Tata Kelola Perusahaan terhadap Nilai Perusahaan. E-Jurnal Akuntansi Universitas Udayana, Vol. 15, No. 1, 667-694.

Rehman, Syed Sh ah Fasih Ur. 2015. Relationship between Financial Leverage and Financial Performance: Empirical Evidence of Listed Sugar Companies of Pakistan. Global Journal of Management and Business Research Finance, Vol. 13, No. 8, 32-40.

Rizqia, Dwita Ayu, Siti Aisjah, dan Sumiati. 2013. Effect of Managerial Ownership, Financial Leverage, Profitability, Firm Size, and Investment Opportunity on Dividend Policy and Firm Value. Research Journal of Finance and Accounting, Vol.4, No. 11, 120-130.

Subramanyam, K. R. 2014. Financial Statement Analysis, Eleventh Edition. New York: McGraw-Hill Education.

Susilowati, Yeye dan Tri Turyanto. 2011. Reaksi Signal Rasio Profitabilitas dan Rasio Solvabilitas terhadap Return Saham Perusahaan. Dinamika Keuangan dan Perbankan, Vol. 3, No. 1, 13-17. 
Syafrizaliadhi, Adhitya Dasha dan Erman Denny Arfianto. 2014. Faktor-Faktor yang Mempengaruhi Perilaku Cash Holdings pada Perusahaan Besar dan Perusahaan Kecil. Diponegoro Journal of Management, Vol. 3 , No. 3, 1-14.

Tarjo. 2008. Pengaruh Konsentrasi Kepemilikan Institusional dan Leverage terhadap Manajemen Laba, Nilai Pemegang Saham serta Cost of Equity Capital. Simposium Nasional Akuntansi, Pusat Data Ekonomi dan Bisnis Universitas Indonesia

Weston, J. Fred dan Thomas E. Copeland. 1991. Manajemen Keuangan. Jilid 2. Edisi Kedelapan. Diterjemahkan oleh: Yohanes Lamarto dan Mariana Adinata. Jakarta: Erlangga. 
